\title{
13. Rural Development: Back on the Agenda in the Western Pacific?
}

\begin{abstract}
Matthew G. Allen
Le développement rural : de nouveau à l'ordre du jour dans le Pacifique occidental?

Après des décennies pendant lesquelles on l'avait négligé, le développement rural, en particulier l'agriculture, est bien de nouveau à l'ordre du jour de l'assistance mondiale au développement. Cette tendance semble se refléter dans la région du Pacifique occidental, où quelques projets de développement rural bien dotés par les donateurs ont soit été récemment lancés soit le seront bientôt. Toutefois, si le développement rural peut être de nouveau à l'ordre du jour des donateurs, il l'a toujours été pour les Mélanésiens, dont la majorité habite des zones rurales. Le développement continue à être le discours dominant qui nourrit tous les domaines de l'Etat et de la société. Il continue également à être très contesté et devient de plus en plus politisé. Avec l'engagement récent par les donateurs dans le développement rural, il serait opportun de revisiter quelques-uns des débats les plus en vue sur le développement en Mélanésie et la question clé de savoir quelle sorte de développement rural est la plus appropriée. Pour explorer ces questions, cet article puise dans une partie de la recherche récente et du travail de consultant de l'auteur en Papouasie-Nouvelle-Guinée et aux Îles Salomon.
\end{abstract}

\section{Introduction}

After decades of neglect, agriculture and rural development are very much back on the global development aid agenda. The revival of donor interest in agriculture and rural development has been enabled by broader shifts in aid priorities and delivery mechanisms, particularly the move from the structural adjustment programs of the 1980s and 1990s to the local and communitylevel engagement strategies that increasingly characterise contemporary aid programming. The Millennium Development Goals, the global food crisis, and the 2008 World Development Report - which had as its theme 'Agriculture for Development' - have also variously contributed to the renewed donor impetus to agriculture and rural development. 
It is not my intention here to describe and analyse the extent to which these trends have been mirrored in the Pacific Islands context. Indeed, the absence of readily available disaggregated data makes it difficult to do so. Having said that, a number of recently commenced, or soon to commence, agriculture and rural development programmes in the Western Pacific would appear to provide at least anecdotal evidence for renewed donor interest in these sectors. Two such projects in Solomon Islands, for example, are the recently-commenced Rural Development Program, jointly funded by the World Bank, AusAID and the European Union; and the AusAID-funded Rural Livelihoods Program, which is at an advanced stage of project design. Similarly, donors in Papua New Guinea are increasingly engaging at the sub-national level, engagements that have significant rural development dimensions, all the more so if we are to include service delivery under the rubric of rural development as I believe we should. Importantly, donors are accompanying these local and community-level engagements with rigorous political economy analysis.

Rather than exploring the question of whether or not rural development is back on the agenda in the Western Pacific, I instead want to ask whether it has ever been off the agenda? While there may indeed be renewed donor and, in some cases, 'recipient' government interest in rural development, if one was to pose this question to a Melanesian, be a they a villager or a Member of Parliament, the response would be that rural development is, and has always been, firmly on the agenda. Development is the dominant discourse in postcolonial Melanesia and, as the vast majority of Melanesians continue to reside in rural areas, development discourse remains inescapably concerned with rural development including, importantly, the delivery of public goods and services.

In an interview on Al Jazeera in 2009, Michael Somare, Prime Minister of Papua New Guinea, denied the existence of poverty in Papua New Guinea. This statement spawned a lively discussion on the Association of Social Anthropologists of Oceania email list (known as ASAO net). The debate was peppered with words like poverty, livelihoods, food security, subsistence, exchange economies, cash economies, capitalism, culture and development. I was simultaneously struck by the extent to which these issues remain highly contested and unresolved on the one hand, and by how little some of us have learned from the story thus far on the other. Romanticism about idealised traditional lifestyles, characterised by subsistence abundance and social and ecological harmony, persists even amongst those who purport to have expert knowledge on these matters. The debate eventually and inevitably settled around the time-honoured dialectic of tradition and modernity, and to the similarly perennial question of what type of development is appropriate for rural Melanesia?

That is the question I explore in this short essay. What type of development is appropriate for rural Melanesia? While this is obviously a question that 
Melanesians themselves are best placed to answer, bearing in mind that their perspectives are by no means unitary or homogenous, I proceed from the position that informed outsiders, 'outlanders' to borrow Margaret Jolly's term, also have a valid voice and role in the debate. However, rather than attempting to offer a definitive answer to this question, I instead intend to frame it by discussing a number of other questions which contextualise and enrich the discussion, and provide some support for the tentative conclusions that are offered.

These questions include: How has development played out in Melanesia? What does it look like? What has been the role of the state? To what extent has rural development become politicised? How much agency have local people had in forging their own development trajectories? I will base my observations on a number of diverse activities I have been undertaking over the past two years: teaching an undergraduate course on conflict and development in Melanesia; undertaking an analysis of the political economy of rural service delivery in Papua New Guinea; and preparing a research proposal to investigate the socioeconomic dimensions of smallholder oil palm production in Solomon Islands.

\section{Theoretical Matters}

First I change lexicon in order to delve briefly into matters theoretical and, in particular, to locate my discussion and approach within the development studies literature. Most readers will be familiar with the successive phases and perspectives in development theory: from modernisation through to structuralism (encompassing dependency and world-system theory), then to poststructuralism and, most recently, to postdevelopment which of course is strongly informed by postmodernism.

Many contemporary development studies scholars agree that development has not seen the universal disintegration of culture and traditional societies in the face of capitalist modernisation that was posited by modernisation theorists. Similarly, developing countries of the so-called periphery have not been permanently subjugated as providers of labour to be exploited by the capital-intensive core, as theorised by the structuralists. And postdevelopment and postmodernism, with what geographer John Connell describes as their 'comprehensive yet totally intellectual assault on the foundations of modernism' have, Connell continues, 'largely failed to shake off the perceived virtues of modernity, whether in villages or parliaments, in boardrooms or international institutions' (Connell 2007:122). Governments need to raise revenue to provide public goods and perform essential functions. People in rural communities want to earn money to pay for school fees, kerosene, clothes, soap, and imported food. Postdevelopment's pronouncement of the end of capitalism clearly seems premature. 
Where, then, does Melanesia fit in this theoretical schema? Poststructuralists those who see the contours of development in terms of hybridity and syncretism - appear to have much to offer in the context of rural Melanesia. This perspective enables us to account for the persistence and 'robustness of indigenous economic and cultural forms' (Curry and Koczberski 1998:31). It enables us to consider social and cultural logics, as well as purely economic ones, as salient shapers of place-based development outcomes and trajectories. It implicitly emphasises the social embeddedness of economic activity and decision-making. ${ }^{1}$

\section{Social Embeddedness}

Economic geographer George Curry applies a social embeddedness framework to his analysis of the relationships between smallholder palm oil production and the local gift-exchange economy in West New Britain Province of Papua New Guinea. He employs palm oil production data, interviews conducted with smallholders, and ethnographic observations to demonstrate that the timing and extent of smallholder engagement with the cash economy is significantly determined by the level of activity in the indigenous exchange economy, which in turn is underpinned by the need to maintain social relations and group identity (Curry 2003:412-418).

Similar patterns and relationships are seen in the ways in which labour is organised and mobilised to produce palm oil (which is often along kinship lines), and in the practice of trade stores extending loans and credit to enable smallholders to respond to unanticipated requirements for gift-exchange, such as funerals. Curry (1999) and fellow geographer Glenn Banks (1999) reported similar findings in their studies of trade stores in parts of East Sepik Province and the Highlands respectively. Preliminary investigations into smallholders' engagements with a commercial oil palm operation on Guadalcanal in Solomon Islanders indicate that similar processes are also at play there (Fraenkel et al. 2010:70-71).

Curry argues that the West New Britain palm oil example demonstrates how smallholders' engagements with one another and with an ostensibly capitalist economic activity are transformed through 'place-based practices', in this case gift-exchange and its importance in maintaining social relations, to create a hybrid modernity that 'bears little resemblance to the idealised notions of market economic relationships and the economically rational, utility maximising individual' (Curry 2003:406).

1 There is expanding body of literature that addresses the social embeddedness of economic activity and decision-making, both internationally (see Zukin and DiMaggio 1990 for an overview) and in the particular case of Papua New Guinea (see for example Gregory 1982; Banks 1999; Curry 1999, 2003, 2005). 
Importantly, the social embeddedness framework provides a robust critique of the Marxist inspired structuralist perspectives applied by earlier scholars of Papua New Guinea's development trajectory of whom Amarshi, Good and Mortimer (1979) and Thompson and MacWilliam (1992) are exemplars. These researchers shared a conceptualisation of capitalism as a monolithic, hegemonic and homogenising force and argued that the penetration of global capitalism would inevitably 'result in the destruction of non-capitalist societies and their infrastructure' (Curry 2003:407). Poststructuralist perspectives such as that offered by Curry (2003) and Connell (2007) are of considerable analytical importance for our purposes as they emphasise the importance of hybridity, syncretism, agency, and the influence of culture:

In this view socially and culturally constructed place becomes important for shaping patterns of interaction at the local level. Agency is therefore recognized, and the assumption of a hegemonic capitalism therefore undermined (Curry 2003:408).

Capitalist forces thus played out in different cultural universes as did all other alien introductions such as Christianity, cricket, clocks and law (Connell 2007:124-125).

\section{Extractive Resource Industries}

I change tack now to consider the local development discourses surrounding large-scale extractive resource industries, especially mining and logging. Why have so many rural communities throughout PNG and Solomon Islands allowed these activities to occur on their land in spite of their demonstrable ability to cause severe environmental and social harm? For Filer and MacIntyre, writing in regard to mining in PNG the answer lies, at least partly, in the failed 'promise that wealth generated by mining would strengthen the state and increase its capacity to improve services across the nation...' (Filer and MacIntyre 2006:227). A collection of essays on mining in PNG edited by Filer and MacIntyre reveals:

the ways that mining, in spite of the problems it generates, appears to be a sure way that local people can gain employment, business opportunities, roads, hospitals, and schools - the development that their government has been unable to deliver...there is sufficient evidence of relative wealth and advantage to feed aspiration among those who have no mine and nostalgia among those whose mine has closed (2006:224).

Of course communities are by no means united nor unified in their views on extractive resource projects. One need only look as a far as Russel Hawkin's documentary Since the Company Came or Martin Maden's more recent Crater 
Mountain Story to see just how locally-contested and divisive such projects can be. In some instance these competing local perspectives map onto broader epistemological contestations manifest as competing visions for development. For example, in the only detailed study to date of the social impacts of commercial logging in a particular locality in Solomon Islands, Kolombangarra, Ian Scales identifies:

a fractionation of local society into groups competing for 'large scale' or 'small scale' forest resource development. The crosscutting social differentiation drives conflict between 'entrepreneurial landowners' and 'traditionalist smallholders' over forest resources and generates competing island-level political associations (Scales 2003:iv).

In other instances the localised contestation over extractive resource projects takes on salient gender dimensions. Frequently it is women who articulate the greatest opposition to mining and commercial logging activities, more so perhaps in matrilineal societies such as Bougainville, Guadalcanal and Western Solomons.

\section{The Politicisation of State Development Funds}

I return now to Filer's and MacIntyre's point about communities' enthusiasm for mining and logging being driven by the failure or inability of the state to provide services. Ironically, the failure of state service delivery has been used to justify the increasing politicisation of the state development budgets, most notably in Papua New Guinea and Solomon Islands. Here I am talking about the so-called slush funds, the District and Provincial Support Grants and, more recently, the District Services Improvement Program in Papua New Guinea; and the Rural Constituency Development Fund in Solomon Islands.

Supporters of such funds argue that they were initially devised as a useful way of capitalising on MPs' intimate knowledge of their electorates and bypassing bureaucratic bottlenecks to fund critical infrastructure projects to the benefit of the whole electorate (Ketan 2007:8-14). However, in the case of Papua New Guinea, the history of constituency development funds is perhaps best seen in the context of so-called decentralisation reforms. The 1995 Organic Law on Provincial Governments and Local Level Governments (OLPGLLG) and subsequent amendments can be interpreted as a successful attempt by national level politicians, particularly Open MPs, firstly to remove their competitors in the form of elected provincial representatives, and then to gradually increase the volume of resources directly channelled into the district level over which they have developed significant de facto and de jure control. 
Described by one informed commentator as 'a kind of decentralisation race to the bottom' (Whimp 2009:3), a string of amendments to the OLPGLLG have seen the establishment of district-level committees over which Open MPs have significant control; the removal of Regional MPs from these committees; and, most recently, the removal of Local Level Government (LLG) presidents from provincial assemblies arguably providing Open MPs with more power and leverage vis a vis provincial governors. ${ }^{2}$ Alongside these developments was the increase in District Support Grants, but not Provincial Support Grants, to a maximum of K1.5 million for each Open MP in 1999 (though we must also note the bearing that the machinations of parliamentary politics have had on the capricious nature of these allocations); and, most recently, the dramatic increase in the District Services Improvement Program grant to K4 million, K6 million and K4 million per district in 2007, 2008 and 2009 appropriations.

De facto arrangements have included the deliberate marginalisation of LLG presidents, and even District Administrators, from district level decision-making processes, meaning that the significant amount of funds now being channelled through the districts can be, and are being, used for pork-barrel politics (see Allen and Hasnain 2010:16-17). This comes at the cost of good service delivery outcomes not only because projects are targeted at MPs' voter strongholds at the expense of the wider electorate, but also because there is a strong emphasis on capital investments made with scant regard to provincial, district, LLG or ward planning processes and, therefore, to on-going operational funding.

Importantly these developments have not been driven by the dictates of 'rational actor' political economy alone. Like the economic behaviour described earlier in relation to hybrid forms of modernity, political behaviour in postcolonial Melanesia is also significantly determined by social and cultural logics. Elected representatives and public servants at all levels of government continue to be enmeshed in social networks of reciprocity and obligation (see, in particular, Morgan 2005). Their kinship groups, which in the case of elected representatives are often coterminous with their political support bases, expect them to distribute and share whatever resources they can access.

This hybridity is not restricted to the behaviour of MPs and government officials; it characterises state institutions throughout postcolonial Melanesia. Reviewing the literature on the relationships between local political cultures and the formal state in Melanesia, much of which is concerned with Papua New Guinea, Morgan concludes that 'pre-existing social forms pervade the state at almost every level' (Morgan 2005:4). Indeed, there is widespread support in the

2 The Papua New Guinea Supreme Court has recently ruled the 2006 amendment to be unconstitutional, which would appear to pave the way for LLG presidents to be reinstated to Provincial Assemblies (National, 7 June 2010). 
Politics, Development and Security in Oceania

literature for the proposition that the introduced state in Papua New Guinea has become thoroughly indigenised (Gordon and Meggitt 1985, Standish 1992, Ketan 2000, Morgan 2005).

\section{Conclusion}

While rural development may be back on the agenda for donors, it has never been off the agenda for the predominantly rural inhabitants of Melanesia. It is a discourse that remains enmeshed in historical and contemporary imaginings of the state - 'the government' - as a provider of services and public goods. Indeed it is the failure of state to provide services and generate economic opportunities that arguably informs Melanesians' desire to host extractive resource projects, even amongst communities which have directly experienced the catastrophic social and environmental impacts of such projects. Ironically, the failure of state service delivery has also been used to justify the increasing politicisation of development budgets, at least in Papua New Guinea and Solomon Islands, thereby further undermining the equitable allocation of public goods.

In this short essay, I have argued that social and cultural logics, as well as economic ones, have shaped the ways in which development, and development discourses, have played out in postcolonial Melanesia. The cases examined have highlighted the dangers inherent in the bifurcation and dichotomisation that continues to characterise much of policy and even scholarly discourse about development in Melanesia: modern versus traditional; rural versus urban; informal versus informal. Such bifurcation is counterproductive at best. Hybridity as it has been elucidated here is best seen as total and complete merging: the emergence of new and complete socio-economic forms which are a 'vibrant blend of modern and pre-modern, of capitalist and pre-capitalist phenomena, where the boundaries are continually shifting and indistinct' (Curry and Koczberski 1998:48).

What, then, is the most appropriate form of development for rural Melanesia? I reemphasise that this is a question which Melanesians are best placed to answer as demonstrated eloquently by Solomon Islander scholar David Gegeo's exposition of the West Kwara'ae (a region of Malaita) philosophy of gwaumauri'anga, meaning the 'good life' (1998:75). The philosophy encapsulates a holistic approach to 'rural development' which caters for spiritual, psychological and physical needs - in addition to economic goals - and is firmly anchored in indigenous knowledge (Gegeo 1998:73-74). Gegeo contrasts this philosophy with government approaches to development which villagers describe as 'a onesided vision'. Villagers believe that this disjuncture has led to the inevitable failure of official rural development projects in the region. The philosophy of 
gwaumauri'anga is echoed in the Papua New Guinea Tok Pisin phrase 'gutpela sindoan', perhaps also best translated as a highly localised conception of the 'good life'.

These conceptions underscore the salience of local epistemologies of development, of the dialectics of people and nature, and of the connections between land and identity. They also point to the growing recognition that Melanesians' engagements with capitalist economies are inflected to serve placebased socio-economic and cultural goals as they seek to achieve a meaningful blend of modernity and tradition. The forgoing discussion has thrown up some implications for development practice. Having applied a social embeddedness framework to his analysis of smallholder oil palm producers' engagements with the cash economy in Papua New Guinea, Curry (2003) offers two such implications which warrant restating here. First, modes of production and marketing should be flexible enough to respond to the demands of the giftexchange economy. Second, development interventions should be conscious of the ways in which surpluses can be appropriated by the exchange economy. This appropriation is more problematic in the case of ventures that require high levels of operating capital.

\section{References}

Allen, M.G., and Hasnain, Z. (2010). 'Power, pork and patronage: decentralisation and the politicisation of the development budget in Papua New Guinea'. Commonwealth Journal of Local Governance. 6: 7-31.

Amarshi, K., Good, K. and Mortimer, R. 1979. Development and Dependency. The Political Economy of Papua New Guinea. Melbourne: Oxford University Press.

Banks, G. 1999. 'Business as usual', in C. Filer (ed.), Dilemmas of Development: The Social and Economic Impact of the Porgera Gold Mine. Canberra: Research School of Pacific and Asian Studies, The Australian National University.

Connell, J. 2007. 'Islands, idyll and the detours of development'. Singapore Journal of Tropical Geography. 28(2): 116-135.

Curry, G. 1999. 'Market, Social Embeddedness and Precapitalist Societies: the Case of Village Tradestores in Papua New Guinea'. Geoforum. 30(3): 285-98.

Curry, G. 2003. Moving Beyond Postdevelopment: Facilitating Indigenous Alternatives for 'Development'. Economic Geography. 79(4):405-423. 
Politics, Development and Security in Oceania

Curry, G. 2005. 'Doing 'Business' in Papua New Guinea: The social embeddedness of small business enterprises'. Journal of Small Business and Entrepreneurship. 18(2): 231-246.

Curry, G., and Koczberksi, G. 1998. 'Migration and circulation as a way of life for the Wosera Abelam of Papua New Guinea'. Asia Pacific Viewpoint. 39(1): 29-52.

Filer, C., and Macintyre, M. 2006. 'Grass Roots and Deep Holes: Community Responses to Mining in Melanesia'. The Contemporary Pacific. 18(2): 215231.

Fraenkel. J, Allen, M.G. and Brock, H. (2010). 'The Resumption of Palm Oil Production on Guadalcanal's Northern Plains'. Pacific Economic Bulletin. 25(1): 64-75.

Gegeo, D.W. 1998. 'Indigenous Knowledge and Empowerment: Rural Development Examined from Within'. The Contemporary Pacific. 10(2): 289315.

Gordon, R., and Meggitt, M. 1985. Law and Order in the New Guinea Highlands. Hanover: University Press New England.

Gregory, C.A. 1982. Gifts and Commodities. London: Academic Press.

Jolly, M. 2007. 'Imagining Oceania: Indigenous and Foreign Representations of a Sea of Islands'. The Contemporary Pacific. 19(2): 508-545.

Ketan, J. 2000. 'Leadership and Political Culture', in M.A. Rynkiewich and R. Seib (eds), Politics in Papua New Guinea: Continuities, Changes and Challenges. Goroka: The Melanesia Institute.

Ketan, J. 2007. 'The Use and Abuse of Electoral Development Funds and their Impact on Electoral Politics and Governance in Papua New Guinea'. CDI Policy Papers on Political Governance 2007/2. Canberra: Centre for Democratic Institutions, The Australian National University.

Morgan, M. 2005. 'Cultures of Dominance: Institutional and Cultural Influences on Parliamentary Politics in Melanesia'. State Society and Governance in Melanesia Discussion Paper 2005/2. Canberra: Research School of Pacific and Asian Studies, The Australian National University.

Scales, I. A. 2003. 'The Social Forest: Landowners, Development Conflict and the State in Solomon Islands'. Unpublished Ph.D. thesis. Canberra: The Australian National University. 
Standish, B. 1992. 'Simbu Paths to Power: Political Change and Cultural Continuity in the Papua New Guinea Highlands'. Unpublished PhD Thesis. The Australian National University.

Thompson, H. and MacWilliam, S. 1992. The Political Economy of Papua New Guinea. Manilla: Journal of Contemporary Asia Publishers.

Whimp, K. 2009. 'If we had funding...Implementing fiscal decentralisation in Papua New Guinea'. Unpublished thesis proposal, February 2009.

Zukin, S. and DiMaggio, P. (eds.). 1990. Structures of Capital: the Social Organization of the Economy. Cambridge: Cambridge University Press. 